\title{
ECONOMIC PERFORMANCE OF LOBLOLLY PINE STANDS IN SOUTHERN BRAZIL AS A RESULT OF DIFFERENT CROWN THINNING INTENSITIES ${ }^{1}$
}

\author{
Mário Dobner $\mathrm{Jr}^{2 *}$ ] and Dagoberto Stein de Quadros ${ }^{3}$
}

\footnotetext{
${ }^{1}$ Received on 13.06.2018 accepted for publication on 01.04.2019.

${ }^{2}$ Universidade Federal de Santa Catarina, Departamento de Agricultura, Biodiversidade e Florestas, Curitibanos, SC - Brasil. E-mail: $<$ mario.dobner@ufsc.br>

${ }^{3}$ Fundação Universidade Regional de Blumenau, Departamento de Engenharia Florestal, Blumenau, SC - Brasil. E-mail: <engdagobert@gmail.com>

*Corresponding author.
}

\begin{abstract}
Approximately 1.6 million hectares of southern Brazil are cultivated with pines, and mainly with the loblolly pine (Pinus taeda L.). More than one third of the stands belong to independent $\log$ producers, whose aim is to maximize their economic results. In this study, a thinning experiment was evaluated over a production period of 30 years. The stands evaluated were submitted to three different crown thinning intensities, with an unthinned stand used as a control. The aim of the study was to evaluate economic criteria regarding realistic discount rates and production periods varying between 16-30 years. For the circumstances that were evaluated, 'extreme' and early release from competition of pruned loblolly pine trees lead to the best economic performance (land expectation value $=\sim 36,000 \mathrm{US} \mathrm{ha}^{-1}, \mathrm{i}=3 \% \mathrm{yr}^{-1}$ ). Stands subjected to crown thinnings, independently of intensity, produced three times the economic output of unthinned and unpruned stands. Although the optimal harvest ages, according to the internal rate of return, are between 18-22 years for thinned and unthinned stands, from a long-term perspective (land expectation value) and for the current relationship between $\log$ price and size, the optimal economic performance requires that production periods are extended (to 24-26 years) from those currently practised in southern Brazil (15-20 years).
\end{abstract}

Keywords: Forest management; Multiple-use management; Land expectation value.

\section{DESEMPENHO ECONÔMICO DE POVOAMENTOS DE PINUS TAEDA NO SUL DO BRASIL SUBMETIDOS A DIFERENTES INTENSIDADES DE DESBASTE POR COPAS}

\begin{abstract}
RESUMO-Aproximadamente 1,6 milhões de hectares são cultivados com Pinus no sul do Brasil, principalmente com Pinus taeda L. Mais de um terço dos povoamentos pertencem a produtores de toras independentes, cujos objetivos são maximizar os resultados econômicos. Neste estudo, um experimento de desbastes foi avaliado durante um período de produção de 30 anos. Os povoamentos avaliados foram submetidos a três diferentes intensidades de desbaste 'por copas', também denominado de 'pelo alto', mantendo uma testemunha não desbastada. Objetivou-se avaliar indicadores econômicos considerando taxas de desconto realistas e períodos de produção entre 16-30 anos. Para as circunstâncias estudadas, a liberação 'extrema' e precoce de competição de árvores podadas de P. taeda alcançou o melhor resultado econômico (valor esperado da terra $=\sim 36.000$ US\$ $h a^{-1}, i=3 \%$ ano $\left.{ }^{-1}\right)$. Povoamentos submetidos a desbastes por copas, independente da intensidade, produziram resultado econômico três vezes maior do que povoamentos sem desbastes e não podados. Embora a idade ótima de corte raso de acordo com a taxa interna de retorno (TIR) seja 18-22 anos para povoamentos desbastados ou não, a partir de uma perspectiva de longo prazo (valor esperado da terra) e para a atual relação preçodimensão da tora, resultados ótimos economicos indicam haver necessidade de prolongar os períodos de produção (24-26 anos) em comparação com a atual prática no sul do Brasil (15-20 anos).
\end{abstract}

Palavras-chave: Manejo Florestal; Manejo para uso múltiplo; Valor esperado da terra.

Silf $(c)$ EY

Revista Árvore 2019;43(2):e430204

http://dx.doi.org/10.1590/1806-90882019000200004 


\section{INTRODUCTION}

Afforestation with pine species is an established and important activity in Brazil, particularly in the south, where approximately 1.6 million hectares are cultivated with this genus (IBÁ, 2017).

Understanding the influences of management strategies on growth and wood quality is an important step for understanding and prescribing silvicultural practices. However, forest owners are mainly interested in the economic aspects of different management options. In this study, a long-term experiment (30 years) was evaluated, providing the opportunity to observe stand development and economic maturity over a longer time period than is currently applied in practice (the normal period is 15-20 years).

The economic aspects of forest management, and particularly the long-term nature of forestry, require consideration of the value of money over time. Discounting methods are used to solve problems with interest calculations, providing satisfactory criteria for profitability and reflecting the magnitude and timing of cash flows (Clutter et al., 1983; Davis and Johnson, 1987; Price, 1989; Straka, 2010).

The definition of the discount rate commonly considers the rate at which money can be borrowed, excluding inflation, or a rate obtained from an alternative investment. However, the discount rate might be overestimated for several previous studies for forestry in Brazil, which used a rate of 6-10\% year${ }^{1}$ (Acerbi Jr. et al., 1999; 2002; Scolforo et al., 2001; Gomes et al., 2002; Silva and Fontes, 2005; Floriano et al., 2009; Souza et al., 2015; Pedroso Filho et al., 2018). As a result, log producers might not be using all the economic potential of forest stands.
With this study, it was aimed at to analyse the economic performance of loblolly pine stands under different crown thinning intensities, assessing the economic criteria of the different management regimes, and using realistic discount rates of 3 and $6 \%$ year $^{-1}$.

\section{MATERIAL AND METHODS}

The stands evaluated in this study were subjected to three different thinning intensities, named 'moderate', 'heavy' and 'extreme', which correlated with the removal of one, two or all competitor trees at the age of five years (Table 1). Further thinnings were also applied. In all thinned variants pruning was also carried out, resulting in pruned log assortments. An unthinned and unpruned variant was conducted as a control, representing the predominant management regime in Brazil, which aims for the maximum volume for biomass (paper and boards).

Thinning variants were established in plots of approximately 0.2 hectares (with an effective area of $\sim 0.1$ ha), randomly distributed over two blocks.

The stand productivity was as high as $45 \mathrm{~m}^{3} \mathrm{ha}^{-1}$ year $^{-1}$ at age 30 years, depending on the management regime, which is a high level of productivity for loblolly pine grown in south Brazil.

Although the experiment was conducted until the age of 30 years, harvests at ages 16, 18, 20, 22, 24, 26 and 28 years were analysed. Comparisons between production periods were based only on land expectation value.

\subsection{Costs and Revenues}

The market prices of the assortments in this study reflect the average state of play in the highlands of

Table 1 - Crown thinning programme characterised by the number of trees remaining (remain.) and the number of competitors (comp.) eliminated in order to favour the potential crop tree candidates

Tabela 1 - Programa de desbaste pelo alto caracterizado pelo número de árvores remanescentes (reman.) e o número de competidoras (comp.) que foram eliminadas com o objetivo de favorecer as candidatas a árvores potenciais.

\begin{tabular}{|c|c|c|c|c|c|c|c|c|}
\hline \multirow{3}{*}{$\begin{array}{c}\text { Age } \\
\text { (years) }\end{array}$} & \multicolumn{8}{|c|}{ Thinning variant } \\
\hline & \multicolumn{2}{|c|}{ without } & \multicolumn{2}{|c|}{ moderate } & \multicolumn{2}{|c|}{ heavy } & \multicolumn{2}{|c|}{ extreme } \\
\hline & remain. & comp & remain. & comp. & remain. & comp. & remain. & comp \\
\hline$\overline{0}$ & 2,500 & & 2,500 & & 2,500 & & 2,500 & \\
\hline 5 & all & - & 2,100 & 1 & 1,700 & 2 & 400 & all \\
\hline 7 & all & - & 1,700 & 1 & 1,300 & 1 & 400 & - \\
\hline 10 & all & - & 1,300 & 1 & 900 & 1 & 250 & 0.4 \\
\hline 13 & all & - & 800 & 1 & 500 & 1 & 150 & 0.4 \\
\hline 15 & all & - & 400 & 1 & 500 & - & 150 & - \\
\hline
\end{tabular}

Revista Árvore 2019;43(2):e430204 
Santa Catarina State, southern Brazil, in 2017. It is important to note that the region has a well-developed forest-based sector, with loblolly pine plantations being the main source of timber. This also implies that the market prices are well regulated by supply and demand.

Log assortments with $10 \mathrm{~cm}$ wide classes, beginning from a small-end diameter (SED) of 10 $\mathrm{cm}$ for unpruned $\operatorname{logs}$ and $20 \mathrm{~cm}$ for pruned ones, are shown in Figure 1. This includes pruned assortments that are larger than those currently commercialised, in order to model the economic impact of larger-sized logs. The logs were $2.5 \mathrm{~m}$ in length.

Pruned logs (the first and second logs) have a higher price level which indicate the premium paid for pruning. This premium was up to $45 \%$ in 2017 , with a larger small-end diameter resulting in a higher premium (Figure 1). The largest-sized assortments currently commercialised in the south Brazilian market are $>35 \mathrm{~cm}$ for unpruned logs and $>40 \mathrm{~cm}$ for pruned ones. However, in the evaluated experiment substantially larger logs were produced and, thus, two new log assortments were evaluated: $>40 \mathrm{~cm}$ for unpruned and $>50 \mathrm{~cm}$ for pruned $\operatorname{logs}$, as part of the sensitivity analysis.

As already mentioned, logs harvested in the stand 'without' thinning were left unpruned in order to give a faithful representation of a pulpwood management regime.

The costs of each activity related to stand establishment, as well as cultural and silvicultural

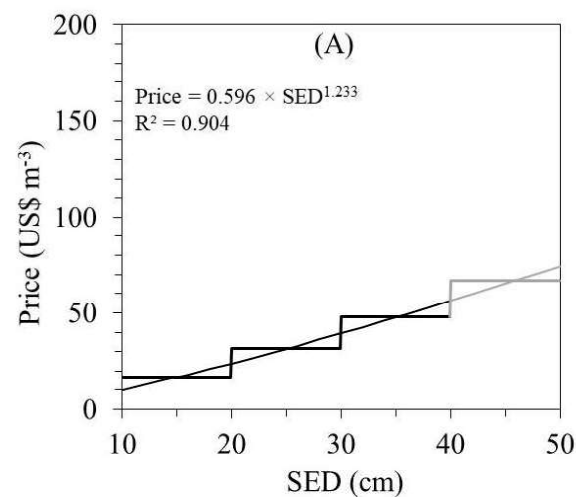

treatments and their productivity (man-day $\mathrm{ha}^{-1}$ ), are shown in Table 2. Values have been rounded to the nearest tenth for simplicity purposes.

The data reflect a moderately sloped area, which is the average condition for forestry in southern Brazil where Forest Stewardship Council (FSC) standards are applied.

Establishment costs were planned at year 1 because year 0 is commonly the year in which the previous cycle is harvested, and the area is prepared for planting.

For the calculation of NPV and IRR a land value of 7,000 US\$ ha ${ }^{-1}$ was inserted and removed from the cash flow at year 0 and at the end of the production cycle, respectively. Land costs were not regarded for the calculation of LEV, as conceptually defined. Administrative costs of 125 US\$ year ${ }^{-1}$ ha $^{-1}$ were included.

\subsection{Economic criteria}

Three methods were applied to conduct economic evaluations using capital budgeting criteria: net present value (NPV), internal rate of return (IRR) and land expectation value (LEV). The NPV is the application of present value equations, and was calculated by adapting the method used by Klemperer (1996):

$$
\mathrm{NPV}=\sum_{\mathrm{t}=0}^{\mathrm{n}}\left[\frac{\left(\mathrm{R}-\mathrm{C}_{\mathrm{t}}\right)}{(1+\mathrm{i})^{\mathrm{t}}}\right]
$$

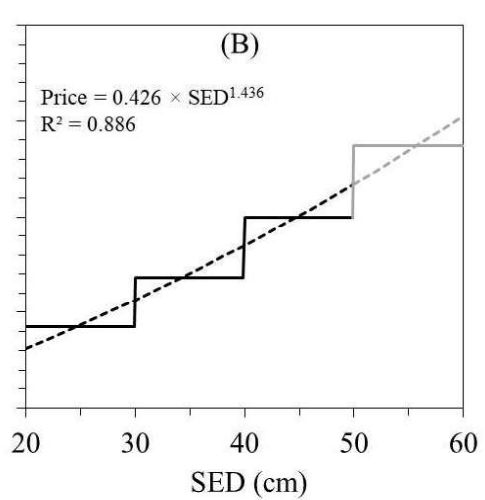

Figure 1 - Regression curves for delimitation and pricing of assortments of unpruned (A - full line) and pruned (B - dashed line) logs depending on the small-end diameter (SED). Real (black segment) and projected (grey segment) values.

Figura 1 - Curvas de regressão para definição dos preços dos sortimentos de tora sem poda (A - linha cheia) e podada (B - linha tracejada), dependendo do diâmetro da ponta fina (DPF). Valores reais (preto) e projetados (cinza). 
Table 2 - Productivity and costs for each of the activities within a rotation cycle of Pinus taeda wood production in southern Brazil. Tabela 2 - Produtividade e custos das atividades que compreendem o ciclo de produção de madeira de Pinus taeda no sul do Brasil.

\begin{tabular}{|c|c|c|c|c|}
\hline Establishment & & $\begin{array}{l}\text { Productivity } \\
\text { man-day ha }{ }^{-1}\end{array}$ & $\begin{array}{c}\text { Cost } \\
\text { US\$ ha- }\end{array}$ & Considerations \\
\hline Area cleaning (manual) & & 16.9 & 510 & $30 \%$ of the area (sloped) \\
\hline Area cleaning (mechanised) & & 0.5 & 360 & $70 \%$ of the area \\
\hline Planting & & 8.3 & 450 & \\
\hline Control of leaf-cutting ants & & 0.8 & 40 & \\
\hline Replanting & & 0.2 & 50 & if needed \\
\hline Total establishment & & & 950 & year 1 \\
\hline \multicolumn{5}{|l|}{ Cultural treatments } \\
\hline $\begin{array}{l}\text { Manual mowing } \\
\text { (sloped) }\end{array}$ & & 3.8 & 130 & $30 \%$ of the area at year 0 and 1 \\
\hline Semi-mechanised mowing & & 1.1 & 50 & $70 \%$ of the area at year 0 and 1 \\
\hline Post-emergent herbicide & & 2.7 & 120 & whole area at years 0,1 and 2 \\
\hline Control of leaf-cutting ants & & 0.8 & 30 & Whole area at years 0,1 and 2 \\
\hline \multirow[t]{3}{*}{ Total cultural treatments } & & 220 & year 1 & \\
\hline & & 220 & year 2 & \\
\hline & & 150 & year 3 & \\
\hline \multicolumn{5}{|l|}{ Pruning } \\
\hline & $1^{\text {st }}$ & 2.3 & 120 & $0.0-1.0 \mathrm{~m}$, year 3 \\
\hline & $2^{\text {nd }}$ & 3.2 & 100 & $1.0-2.5 \mathrm{~m}$, year 4 \\
\hline & $3^{\text {rd }}$ & 2.0 & 150 & $2.5-4.2 \mathrm{~m}$, year 5 \\
\hline & $4^{\text {th }}$ & 2.2 & 200 & $4.2-6.0 \mathrm{~m}$, year 6 \\
\hline Harvest & & US\$ $\mathrm{m}^{-3}$ & & \\
\hline \multirow[t]{5}{*}{ Thinning } & $1^{\mathrm{st}}$ & 20 & & \\
\hline & $2^{\text {nd }}$ & 20 & & \\
\hline & $3^{\text {rd }}$ & 15 & & \\
\hline & $4^{\text {th }}$ & 12 & & \\
\hline & $5^{\text {th }}$ & 12 & & \\
\hline$\overline{\text { Final cut }}$ & & 10 & & \\
\hline
\end{tabular}

The cost of one worker day ${ }^{-1}$ includes wages, taxes, social insurance, safety equipment, alimentation and transport; road building and maintenance costs are constant and are integrated into the harvest costs at US\$ $1.80 \mathrm{~m}^{-3}$; harvest costs refer to logs loaded onto a customer's truck, next to the stand. Values are rounded to the nearest tenth.

Where: NPV $=$ net present value, in US $\$ \mathrm{ha}^{-1}, \mathrm{n}=$ number of years involved, $\mathrm{t}=$ year at which revenues were obtained and costs incurred, starting at age $0, \mathrm{R}$ $=$ revenues obtained in period ' $\mathrm{t}$ ', $\mathrm{C}=$ costs incurred in period ' $\mathrm{t}$ ', $\mathrm{i}=$ discount rate.

The IRR was obtained simply by equalling NPV to zero (Clutter et al., 1983). The IRR is the expected yield of the capital invested in the project (Clutter et al., 1983; Klemperer, 1996). The management regime is considered economically attractive when the difference between the IRR and the minimum acceptable rate is equal to or greater than zero. This also means that the NPV is positive.

The LEV was calculated by adapting the formula used by Clutter et al. (1983):

$$
\mathrm{LEV}=\frac{\sum_{\mathrm{j}=0}^{\mathrm{t}}\left(\mathrm{R}_{\mathrm{j}}-\mathrm{C}_{\mathrm{j}}\right)(1+\mathrm{i})^{\mathrm{t} \cdot \mathrm{j}}}{\left((1+\mathrm{i})^{\mathrm{t}}-1\right)}
$$

Conceptually, the LEV is the present value of all cash flows produced by an infinite series of rotations (Clutter et al., 1983). The LEV is commonly used to represent the NPV of a bare piece of land intended for forestry use (Davis and Johnson, 1987). In other words, it represents the maximum price per hectare when land is bought for some specific purpose, and hence, as noted by Klemperer (1996), the willingness to pay for land.

For these calculations, some assumptions are needed.

\subsection{Assumptions}

The following assumptions were considered:

- Exchange rate of R\$3.20 = US\$ 1.00 (Real to United States Dollar, the average for the year 2017).

\section{Revista Árvore 2019;43(2):e430204}


- Real savings interest $=2.84 \%$ year $^{-1}$ (average during the whole period 1994-2017) in real terms, without inflation.

It is important to note that governmental interest rates are quoted in nominal terms, including inflation. Savings interest in nominal terms during the same period (1994-2017) was $11.66 \%$ year $^{-1}$, which implies that inflation averaged $8.58 \%$ year $^{-1}$.

Savings interest is an important reference because it is the safest option, free of taxes. However, it frequently does not compensate for the inflation rate. Savings may not be appropriate as an alternative rate of return for bigger investors. Thus, the capital market in Brazil (Bovespa) was also evaluated. The average nominal growth of Bovespa over the same period 1994-2017 was $13.3 \%$ year $^{-1}$. However, in real terms it was $4.35 \%$ year $^{-1}$. It is important to note how distorted long-term financial analysis can be when inflation is not properly regarded.

Because there is no certainty in estimated future inflation rates, analyses need to be carried out regardless of inflation, assuming that revenues and costs will oscillate in line with similar patterns (Gregersen and Contreras, 1992; Binkley, 2009).

Taking into account these assumptions, and the fact that the discount rate should conceptually be the minimum acceptable rate of return of the capital invested, a real alternative interest rate of $3 \%$ was considered reasonable for the Brazilian scenario and for independent log producers, at least for small to medium-sized ones.

Costs and benefits generated within a given year were considered as having been incurred at the same time. All analyses were conducted on a before-tax basis.

\subsection{Sensibility analysis}

Economic criteria only allow conclusions to be drawn for the specific assumptions on which the analyses are based. However, and because of the intrinsic long-term nature of forestry investment, a sensibility analysis in which some assumptions vary within a determined range while others remain constant might offer more strategic information.

The calculations using the current costs and assortment prices might be viewed as a realistic approach. Additionally, the following scenarios were considered:

- Discount rate of $6 \%$, in addition to the $3 \%$ taken as the basis for this study, which was used for a better evaluation of how decisions are affected by different market or investor assumptions.

- New assortments, $>40 \mathrm{~cm}$ for unpruned and $>50 \mathrm{~cm}$ for pruned $\operatorname{logs}$, created for a complete understanding of the effects of postponing the harvesting age in a more developed log assortment market (Figure 1)

\section{RESULTS}

Even though the number and intensity of thinning procedures varied across the stands, all the thinned stands generated similar total net revenues $(4,500-$

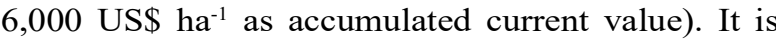
noteworthy that the first thinning, carried out at the age of five years, resulted in negative values in all thinned variants (-300 US\$ ha-1).

Standing stock at age 30 years delivered net revenues of between $27,000-44,000 \mathrm{US} \mathrm{ha}^{-1}$, in the stands 'without' and 'heavy' thinning, respectively. Stands with 'moderate' and 'extreme' thinning showed similar values to those observed in 'heavy'. A proper analysis of these values needs consideration of the value of money in time, which was obtained with help of the cash flow analyses that follow.

\subsection{Economic criteria}

The analysed economic criteria for the stands submitted to different thinning intensities with harvest ages varying between 16-30 years and current log assortment prices are shown in Table 3.

As a consequence of the higher surplus, IRR was higher in the thinned variants and highest in the 'extreme' variant $\left(8.8 \%\right.$ year $\left.^{-1}\right)$, already at the age of 16-18 years. At 18-22 years of age, the variants with 'moderate' and 'heavy' thinning were at a peak, with values slightly lower than the value observed for 'extreme'. The variant 'without' thinning delivered the lowest values $\left(5.4 \%\right.$ year $\left.^{-1}\right)$ already at 16 years of age.

It was verified that thinning substantially increased the NPV obtained from the stands, and also that the NPV was highest for the 'extreme' variant. It is incorrect to compare NPV and IRR across different 
Table 3 - Internal rate of return (IRR), net present value (NPV) and land expectation value (LEV) for the different thinning variants, based on current $\log$ assortment prices and a discount rate of $3 \%$ year ${ }^{-1}$. Harvest ages varied between 16-30 years. NPV and LEV values are rounded to the nearest hundredth.

Tabela 3 - Taxa interna de retorno (TIR), valor presente líquido (VPL) e valor esperado da terra (VET) para as diferentes variações de desbaste, baseado em preços atuais de sortimentos de toras e uma taxa de desconto de $3 \%$ ano ${ }^{-1}$. As idades de corte raso variam entre 16-30 anos. Valores de VPL e VET estão arredondados para a centena mais próxima.

\begin{tabular}{|c|c|c|c|c|}
\hline \multirow{2}{*}{$\begin{array}{l}\text { Production } \\
\text { period }\end{array}$} & \multicolumn{4}{|c|}{ Internal rate of return - IRR (\%) } \\
\hline & without & moderate & heavy & extreme \\
\hline 16 & 5.4 & 7.4 & 7.4 & 8.8 \\
\hline 18 & 5.2 & 7.7 & 7.8 & 8.8 \\
\hline 20 & 5.1 & 7.7 & 7.7 & 8.2 \\
\hline 22 & 5.1 & 7.7 & 7.7 & 8.2 \\
\hline 24 & 4.9 & 7.5 & 7.4 & 7.8 \\
\hline 26 & 4.8 & 7.2 & 7.1 & 7.4 \\
\hline 28 & 4.5 & 6.9 & 6.7 & 7.0 \\
\hline 30 & 4.3 & 6.6 & 6.4 & 6.6 \\
\hline Production & \multicolumn{4}{|c|}{ Net present value - NPV (US\$ ha ${ }^{-1}$ ) } \\
\hline period & without & moderate & heavy & extreme \\
\hline 16 & 4,500 & 9,400 & 9,400 & 13,400 \\
\hline 18 & 4,900 & 11,600 & 12,000 & 15,600 \\
\hline 20 & 5,200 & 13,200 & 13,500 & 16,400 \\
\hline 22 & 5,600 & 15,300 & 15,300 & 17,300 \\
\hline 24 & 6,200 & 16,800 & 16,400 & 18,300 \\
\hline 26 & 6,300 & 17,200 & 16,600 & 17,500 \\
\hline 28 & 5,200 & 16,100 & 15,500 & 16,300 \\
\hline 30 & 4,900 & 15,600 & 15,100 & 15,300 \\
\hline Production & \multicolumn{4}{|c|}{ Land expectation value - LEV (US\$ ha $\left.{ }^{-1}\right)$} \\
\hline period & without & moderate & heavy & extreme \\
\hline 16 & 7,700 & 20,200 & 20,000 & 30,200 \\
\hline 18 & 9,000 & 24,600 & 25,500 & 33,700 \\
\hline 20 & 10,100 & 27,400 & 28,000 & 34,300 \\
\hline 22 & 11,200 & 30,900 & 30,800 & 34,800 \\
\hline 24 & 12,500 & 33,300 & 32,400 & 36,200 \\
\hline 26 & 12,600 & 33,100 & 31,900 & 33,607 \\
\hline 28 & 10,800 & 29,800 & 28,700 & 30,100 \\
\hline 30 & 10,400 & 28,300 & 27,400 & 27,800 \\
\hline
\end{tabular}

production periods, and thus the optimal harvest age from an economic point of view cannot be traced using these criteria.

The LEV reflects the present value of managing an area with the specific regime in perpetuity. It is, therefore, a criterion that allows comparisons between different production periods. This criterion shows that, in the long run, managers of loblolly pine stands should consider production periods of between 24-26 years, depending on the thinning intensity. According to this criterion, thinned stands delivered more than three times as much surplus as unthinned stands.

\subsection{Sensibility analysis}

Sensibility analyses were carried out in order to understand how discount rate and two new log assortments would influence the conclusions of the present study. A scenario in which a discount rate of $6 \%$ year $^{-1}$ was considered and another one in which it was supposed that there would be interest in the market in paying more for unpruned logs of smallend diameter of $>40 \mathrm{~cm}$ (US\$ $67 \mathrm{~m}^{-3}$ ) and one new pruned assortment ( $>50 \mathrm{~cm}$, US\$ $137 \mathrm{~m}^{-3}$ ). Results are presented in Figure 2. For simplicity reasons, scenarios are only analysed from the land expectation value (LEV) perspective, which provides robust and long-term conclusions.

Interest rates dramatically affected the LEV. It became obvious that with high alternative real interest rate markets $\left(6 \%\right.$ year $\left.^{-1}\right)$, unthinned stands are only marginally profitable. Although the LEV of all the thinned stands suffered a negative influence

Revista Árvore 2019;43(2):e430204 

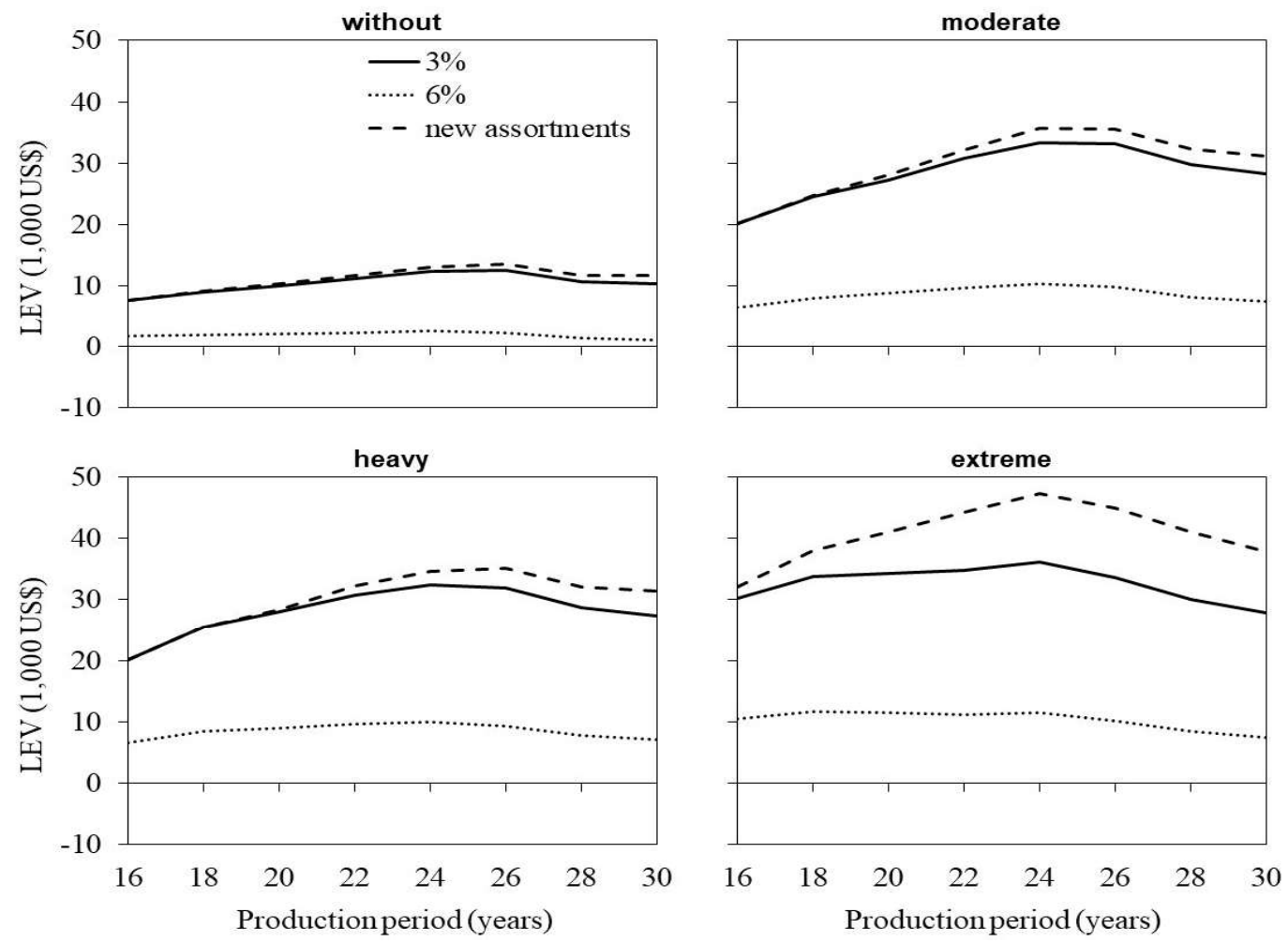

Figure 2 - Sensibility analysis for land expectation value (LEV) as affected by the new log assortments scenario ( $>40$ cm for unpruned and $>50 \mathrm{~cm}$ for pruned $\operatorname{logs}$ - dashed line), and the scenario with a discount rate of $6 \%$ year $^{-1}$ (dotted line), compared with the standard analysis (3\% year ${ }^{-1}$, current $\log$ assortment market). Production periods varying between 16-30 years.

Figura 2 - Análise de sensibilidade para o valor esperado da terra (VET) para o cenário com os novos sortimentos de tora $(>40 \mathrm{~cm}$ para as toras não podadas e $>50 \mathrm{~cm}$ para as podadas - linha tracejada), e o cenário com taxa de desconto de $6 \%$ ano ${ }^{-1}$ (linha pontilhada), em comparação com a análise padrão (3\% ano-1, atual mercado de toras). Períodos de produção variando entre 16-30 anos.

from higher interest rates, their cash flows remained profitable.

The new assortment scenario resulted in additional economic output, which increased in line with more intense thinning. The unthinned stand does not generate a profit when these new assortments are considered, which was expected given that the tree dimensions were smaller. For the 'moderate' and 'heavy' treatments, the new assortment scenario showed a modest effect only after ages 22-24 years. In contrast, in the 'extreme' variant, the economic advantages of the larger-sized assortments were greater and were already noticeable from 18 years of age, peaking at age 24 years as previously observed (Table 3 ).

\section{DISCUSSION}

The revenues across all the thinned stands were similar, regardless of the thinning intensity. This was due the interaction between size and amount of harvested timber. Where a bigger amount of timber was obtained through thinnings, logs were smaller and, therefore, of lower value. However, because of the early and intense release from competition of the selected crop trees in the 'extreme' variant, the thinning at the age of 13 years in this variant already delivered valuable assortments worth US\$ 5,000 ha-1. This is quite impressive and shows the high growth response of young loblolly pine trees when sufficient growth space is provided at an early stage.

The total net revenues at the age of 30 years were higher in the stands with 'moderate' and 'heavy' thinning, where a higher amount of timber was available.

The mean stumpage price at the age of 30 years was highest in the 'extreme' variant (US\$ 300 tree $^{-1}$ ), whereas it was only US\$ 50 tree $^{-1}$ in the stand 'without' thinning.

\section{Revista Árvore 2019;43(2):e430204}


Although pruned log assortments (first $6 \mathrm{~m}$ of the bole) represented only $17 \%$ of the total tree height at age 30 years, they accounted for $\sim 30 \%$ of the total volume produced and $\sim 50 \%$ of the total revenue.

\subsection{Economic criteria}

As mentioned, the alternative interest rates regarded in this study (3 and $6 \% \mathrm{yr}^{-1}$ ) were real, without inflation. According to Klemperer (1996), one of the most common errors is to project cash flows in constant dollars and use a nominal interest rate. The general approach is to disregard inflation and assume that the prices of all inputs and outputs will oscillate at similar rates (Gregersen and Contreras, 1992; Klemperer, 1996).

Most of the previous economic studies for forestry in Brazil applied discount rates that varied between $6-10 \%$ year ${ }^{-1}$. However, such values might be an overestimation of realistic real alternative interest rates, resulting in questionable decisions on managing forest stands. In fact, and according to Cubbage et al. (2007), long-term real rates of return are probably between $4-8 \%$ for most investments, despite higher corporate hurdle rates. Ultimately, it seems realistic, for Brazilian conditions, especially forestry on small to medium properties, to consider real rates of around $3 \%$ year $^{-1}$, which, in nominal terms, would mean $>10 \%$ year $^{-1}$, considering an inflation rate of $8.58 \%$ year ${ }^{-1}$ (average for the period between 1994-2017 the whole Real plan period).

In the United States, Atmadja and Sills (2013) reported an average discount rate of $2.6 \%$ year $^{-1}$, ranging from below 1 to up to 7\%; Bettinger et al. (2009) reported an average discount rate of $4 \%$ as a common value for taxation forestlands, while Mills and Stiff (2013) applied rates of 5-7\% for analysing loblolly and longleaf pine regimes.

Manley $(2010,2012)$ pointed out that economic analyses of $P$. radiata plantations in New Zealand applied interest rates varying between $7-11 \%$. Similar values were reported by Mead (2013) for the same species in Australasia and Chile.

It is important to note that the direct comparison of discount rates between countries are inappropriate because their economic particularities and risks. They have to be taken in account for a deeper understanding. Nevertheless, for the Brazilian scenario and particularities, real interest rates $>3 \%$ seems unrealistic, at least for small to medium-sized log producers.

The results of this study show that, regardless of thinning intensity, the IRR, NPV and LEV were always higher for thinned and pruned than for unthinned and unpruned stands.

For loblolly pine plantations in southern Brazil, higher IRR values than the ones observed in this study have been reported: 16\% (Cubbage et al., 2007), 21\% (Scolforo, 1998; Cubbage et al., 2010) and $27 \%$ (Vitale and Miranda, 2010). According to Cubbage et al. (2010), the IRR for the loblolly pine in southern Brazil was the most profitable in comparison to the IRR for the same species in Argentina (20\% $\left.\mathrm{yr}^{-1}\right)$, Uruguay $\left(13 \% \mathrm{yr}^{-1}\right)$, Paraguay $\left(12 \% \mathrm{yr}^{-1}\right)$ and the United States $\left(8 \% \mathrm{yr}^{-1}\right)$. These results are certainly affected by management regimes, costs, log assortments, tree growth, among others.

Cubbage et al. (2010) evaluated the profitability of loblolly pine plantations in Brazil and found a NPV of US\$ $3,600 \mathrm{ha}^{-1}$. The assumptions made in this study included establishment costs of US\$ $1,050 \mathrm{ha}^{-1}$ (for years $0-5$ ), a discount rate of $8 \%$ year $^{-1}$, and a final cut at 15 years. It is important to note that the study conducted by Cubbage et al. (2010) described the average conditions for the Brazilian pine segment, which mainly produces pulpwood, which is different than the multiple-use management regarded in the present study.

Vitale and Miranda (2010) reported results similar to the ones described in the present study. Because pruning costs were described, one can assume that pruned assortments were considered, although there was no information provided about this. The assumptions of this study were an establishment cost of US\$ $1,940 \mathrm{ha}^{-1}$, and a discount rate of $6.75 \%$ year $^{-1}$, resulting in an NPV of US\$ $15,600 \mathrm{ha}^{-1}$, similar to the ones observed for 'moderate' and 'heavy' treatments in the present study.

The maximum land expectation value (LEV) was verified for the extremely thinned stand $(36,200$ US\$ $\left.\mathrm{ha}^{-1}\right)$. This was due the substantial growth reaction of trees when early and consciously released from competition throughout crown thinnings. So, trees rapidly occupied the growth space delivering bigdimensioned and valuable logs. Based on the long-

Revista Árvore 2019;43(2):e430204 
term perspective provided by the LEV criterion, it can be stated that thinned loblolly pine stands produced more than three times the economic output of unthinned stands.

The conclusions of the present study should be analysed carefully given that the high LEV values obtained were a result of a valuable log assortment production by small to medium independent log producers, which commonly already have the land and are looking for the best strategies for using it. Indeed, previous analyses generated much lower values, from 2,500 US\$ (Cubbage et al., 2007) to 4,400 US\$ ha-1 (Acerbi Jr et al., 2002), which were also affected by higher discount rates.

Scolforo (1998), Gomes et al. (2002) and Acerbi Jr et al. (2002) reached a similar conclusion to the present study, that the most profitable management option for loblolly pine stands in southern Brazil is one that incorporates thinning and pruning.

Regional particularities obviously need to be taken into account, particularly the relationship between log price and size. However, the results of the present study show that for independent log producers located within well-established log markets, the currently applied management strategy of 15-20 years of production cycles are underutilising the economic potential of managed stands.

\subsection{Sensibility analysis}

In addition to the real interest rate of $3 \%$, a scenario with $6 \%$ was also evaluated. The results show that interest rates had the greatest influence on the economic analyses, thus demonstrating the importance of choosing a suitable interest rate for each particular condition.

Discount rates had no influence on the optimum harvest age. For the thinned variants, for both discount rates $(3 \%$ and $6 \%)$, the optimum harvest age was approximately 24 years (Fig. 2).

The 'new assortments' scenario was conducted mainly on the basis of the industrial analysis of the logs produced in the same experiment. Analyses of logs for sawmill (Dobner Jr et al., 2012) and the rotary peeling process (Dobner Jr et al., 2013) detected that the industrial yield of logs with diameter of more than $50 \mathrm{~cm}$ was substantially higher than that of smaller $\log$ assortments.
The new assortment scenario resulted in a substantial increase in the economic performance of thinned stands, whereas that of unthinned stands was not affected. The LEV of 'moderately' and 'heavily' thinned stands increased as a result of new assortments only after 22-24 years of age, whereas the 'extreme' variant underwent a dramatic increase even at the age of 18 years. It is important to note, however, that including bigger-sized log assortment classes led to no postponement of the optimum final cut age.

Although the 'extreme' variant resulted in the highest economic performance, it is noteworthy that there are also high silvicultural risks related to such an extreme management regime and, therefore, its commercial applicability is discouraged. However, the high growth response of potential crop trees as a result of early and intense liberation of competition (crown thinning) clearly indicate that thinnings should not be postponed and that there is almost no limit to their intensity as long as there are enough crop trees per hectare for the final cut.

The results of this study contradict the prevailing idea in Brazilian forestry that better economic results are obtained by shortening production periods, which, in turn, are responsible for the current market trend of using small-sized logs formed mainly by juvenile wood (Dobner Jr et al., 2018). It has been demonstrated that this trend has led to an underutilisation of the growth and economic potential of loblolly pine stands, at the same time the wood industry struggles with the supply of low-quality timber.

\section{CONCLUSIONS}

The results demonstrate that thinning in combination with pruning is a profitable practice in loblolly pine stands in southern Brazil. Discounting cash flows with realistic interest rates resulted in impressively high economic outputs. This means that the interaction between tree growth and assortment prices is more efficient in the long term than an alternative investment earning of 3 or even $6 \%$ year $^{-1}$ (real rates).

Given the assumptions of the present study, stands subjected to crown thinning, independently of the thinning intensity, result in more than three times the economic output of unthinned and unpruned stands. For the evaluated circumstances, 'extreme' 
and early release from competition of pruned loblolly pine trees led to the best economic performance (LEV $=\sim 36,000 \mathrm{US} \$ \mathrm{ha}^{-1}, i=3 \% \mathrm{yr}^{-1}$ ) over a production period of 24 years.

Although optimum harvest ages according to the IRR are 18-22 years for thinned and unthinned stands, from a long-term perspective (as indicated by the LEV), optimum economic performance in terms of LEV requires production periods of 24-26 years.

\section{ACKNOWLEDGEMENTS}

The authors are grateful to Prof. Dr. Dr. Jürgen Huss (Uni-Freiburg, Germany), who designed and established the field experiment in the 1980s; we also wish to thank the private enterprise Florestal Gateados for enduring support.

\section{REFERENCES}

Acerbi Jr FW, Scolforo JRS, Oliveira AD, Maestri R. Simulation and economic evaluation of thinning regimes for Pinus taeda for obtaining wood multiproducts. Cerne. 1999;5(1):81-102.

Acerbi Jr FW, Scolforo JRS, Oliveira AD, Maestri R. Growth and yield prognosis model and economic evaluation of several management regimes for Pinus taeda L. Revista Árvore. 2002;26(6):699-713.

Atmadja SS, Sills EO. Forest management and landowners' discount rates in the Southern United States. In: Kant S, editor. Post-Faustmann forest resource economics. Springer, 2013. p.91-123. cap. 5 .

Bettinger P, Boston K, Siry JP, Grebner DL. Forest management and planning. Burlington: Academic Press; 2009.

Binkley CS. Valuing emerging market forestry investments. Cambridge: IFIA LLC; 2009. (IFIA Working Paper).

Clutter JL, Forston JC, Pienaar LV, Brister GH, Bailey RL. Timber management: A quantitative approach. New York: John Wiley \& Sons; 1983.

Cubbage F, MacDonagh P, Sawinski Jr J, Rubilar R, Donoso P, Ferreira A, et al.Timber investment returns for selected plantations and native forests in
South America and the Southern United States. New Forests. 2007;33:237-55.

Cubbage F, Koesbandana S, MacDonagh P, Rubilar R, Balmelli G, Morales Olmos V, et al. Global timber investments, wood costs, regulation, and risk. Biomass and Bioenergy. 2010;34(12):1667-78.

Davis LS, Johnson KN. Forest management. 3rd ed. New York: McGraw-Hill; 1987.

Dobner Jr M, Higa AR, Rocha MP. Sawmill yield of Pinus taeda logs: Large assortments. Brazilian Journal of Forestry and Environment. 2012;19(4):385-92.

Dobner Jr M, Nutto L, Higa AR. Recovery rate and quality of rotary peeled veneer from 30-year-old Pinus taeda L. logs in Southern Brazil. Annals of Forest Science. 2013;70(2):429-37.

Dobner Jr M, Huss J, Tomazello Filho M. Wood density of loblolly pine trees as affected by crown thinnings and harvest age in southern Brazil. Wood Science and Technology. 2018;52:465-85.

Floriano EP, Schneider PR, Finger CA, Fleig FD. Economic analysis of the Pinus elliottii yield in the southeastern mountain range, Rio Grande do Sul. Ciência Florestal. 2009;19(4):393-406.

Gomes FS, Sanquetta CR, Scolforo JRS, Graça LR, Maestri R. Technical and economic analysis of factors affecting thinned and unthinned management regimes of Pinus taeda L. Cerne. 2002;8(1):13-31.

Gregersen H, Contreras A. Economic assessment of forestry project impacts. Rome: FAO; 1992. (Forestry Paper, 106)

Indústria Brasileira de Árvores - IBÁ. Relatório 2017. 80p.

Klemperer WD. Forest resource economics and finance. New York: McGraw-Hill; 1996.

Manley B. Discount rates used for forest valuation: Results of 2009 survey. New Zealand Journal of Forestry. 2010;54(4):19-23.

Manley B. Discount rates used for forest valuation: results of 2011 survey. New Zealand Journal of Forestry. 2012;56(4):21-28. 
Mead DJ. Sustainable management of Pinus radiata plantations. Rome: FAO; 2013. (FAO Forestry Paper, 170).

Mills SD, Stiff CT. Financial performance of loblolly and longleaf pine plantations. In: Guldin JM, editor. Proceedings of the 15th Biennial Southern Silvicultural Research Conference. E-gen. Technical Report SRS-GTR-175. Asheville: US Department of Agriculture, Forest Service, Southern Research Station; 2013. p.183-91.

Pedroso Filho JI, Biali LJ, Schneider PR, Farias JA. Economic evaluation of afforestation projects with Eucalyptus grandis Hill ex Maiden implanted under different spacings. Ciência Florestal. 2018;28(1):240-248.

Price C. The theory and application of forest economics. Oxford: Basil Blackwell; 1989.

Scolforo JRS. Manejo florestal. Lavras: UFLA/FAEPE; 1998.
Scolforo JRS, Acerbi Jr FW, Oliveira AD, Maestri R. Simulation and economic evaluation of thinning regimes and pruning to obtain Pinus taeda wood free from knots. Ciência Florestal. 2001;11(1):121-39.

Silva ML, Fontes AA. Discussion on the criteria of economical evaluation: Net present value (VPL), equivalent annual value (VAE) and soil expected value (VET). Revista Árvore. 2005:29(6):931-6.

Souza VS, Timofeiczyk Jr R, Berger R, Silva JCGL, Delacote P. Economic profitability of land lease for Eucalyptus cultivation in Sao Paulo State, Brazil. Floresta e Ambiente. 2015;22(3):345-54.

Straka TJ. Financial breakeven point for competition control in longleaf pine (Pinus palustris Mill.) reestablishment. New Forests. 2010;40:165-73.

Vitale V, Miranda GM. Comparative analysis of the economic viability of Pinus taeda and Eucalyptus dunnii plantations in the south-center region of Parana State, Brazil. Floresta. 2010;40(3):469-76. 